\title{
EVALUATION OF MORPHOFUNCTIONAL STATE OF THE LOWER EXTREMITIES IN PATIENTS WITH IDIOPATHIC COXARTHROSIS STAGE III
}

\author{
Menshchikov I.N. ${ }^{1}$, Menshchikova T.I. ${ }^{1}$, Dolganova T.I. ${ }^{1}$, Dolganov D.V. ${ }^{1}$, Chegurov O.K. ${ }^{1}$, \\ Maltseva L.V. ${ }^{1}$
}

${ }^{1}$ Federal State Budgetary Institution «Russian Research Center» Restorative Traumatology and Orthopedics «named after Academician G.A. Ilizarova Ministry of Healthcare and Social Development of Russia», Kurgan, e-mail: tatmench@mail.ru

Aims.

Aim of the study: to conduct a comprehensive analysis of the morphofunctional state of the lower extremities in patients with idiopathic coxarthrosis stage III.

Materials and methods.

In this study, 25 patients with idiopathic coxarthrosis stage III received static-dynamic examination using the hardware-software complex DiaSled-Scan (Saint Petersburg) for recording, displaying, and processing of information about the pressure distribution dynamics between the foot and the support surface. Dynamometric studies were performed using dynamometers, and US scanning - with the device HITACHI HI Vision Avius.

Results.

It was found that echo-signs of atrophy in the region of $\mathbf{m}$. gluteus maximus and $\mathbf{m}$. adductor longus were most pronounced in the affected segment and compared to the contralateral segment. It is demonstrated that the structural and functional parallels by ultrasound and dynamometric data are unidirectional. Moderate structural changes affected the anterior femoral muscles, with well-differentiated intermuscular septa and bundles of muscle fibres on the affected and contralateral segments. These criteria indicate the presence of reserve capacities of the anterior femoral muscles for rehabilitation.

Conclusions.

Structural and functional parallels by ultrasound and dynamometric data are unidirectional. Decrease in the functional activity of all muscles involved in a locomotor act was a determining factor in the locomotor stereotypes, with recording of compensatory movements of the body frame when walking.

Keywords: coxarthrosis, femoral muscles, ultrasound, dynamometry, podography

\section{INTRODUCTION.}

The core clinical criteria for evaluating the functional status of idiopathic coxarthrosis patients are related to the qualitative and quantitative aspects $[1,2]$ of the integrated biomechanical descriptor of their pathology $[1,2]$. Reduced hip joint mobility reduces the dynamometric capacity of the muscles and lowers the amplitude and speed of spatial limb movements; the condition affects the balance and de-optimizes the walking movements, it alters the posture and inertia of the lower limb and its segments. A characteristic gait appears, in which the torso is tilted towards the affected hip joint [3].

The nociceptive effects of the affected joint inhibit the peripheral part of the neuromotor system in both the affected and the intact limb. Normal functioning of the hip joint greatly depends on the muscles around it: the gluteal and the thigh muscles that function as extra shock absorbers when the person is exercising (walking, running, or jumping) and "deliver" blood to the joint vessels. Muscular pathology affects the joint as well [4].

The literature review did not find any studies that would comprehensively assess the structural condition of bone and cartilage tissue, the contractibility of thigh muscles, and the 
locomotor activity in Stage III idiopathic coxarthrosis patients.

Research Goal. Comprehensive state-of-the-art diagnostic analysis of the morphofunctional status of lower limbs in Stage III idiopathic coxarthrosis patients.

MATERIALS AND METHODS. Twenty-five Stage III idiopathic coxarthrosis (IC) patients (13 women, 12 men, aged 52 to 75 ) underwent a comprehensive outpatient examination. The research was based on Kosinskaya's classification [5]. Limbs of the IC patients were compared in the context of their clinical X-ray status, where the affected limb was the one scheduled for hip replacement, while the contralateral one was deemed conditionally intact. Static and dynamic readings of the foot ground reaction force were provided by a DiaSled Scan device (St. Petersburg, Russia) [6]. Dynamometric tests were run using a device designed by the Ilizarov Center [7]. The readings were: the moment of force found by the indicator head of the dynamometer, and the distance L from the rotational axis of the hip (for hip flexors, extensors, adductors, abductors) and from the rotational axis of the knee (for the tibial flexors and extensors) to the midpoint of the belt grip. The obtained dynamometry readings were compared to the previously published normative data [7]. Echography was performed using a linear sensor on a Hitachi Hi Vision Avius device at 5 to $12 \mathrm{MHz}$. Upon placing the sensor along the femoral neck, movable markers were used to measure the thickness and analyze the structure of $\mathrm{m}$. iliopsoas. Scanning the medial surface of the thigh assessed $\mathrm{m}$. adductor longus, while the lateral surface scan tested m. gluteus medius. M. gluteus maximus tests were run as patients lied on a side and flexed the tested limb in the hip and in the knee to $90^{\circ}$; the sensor was placed between the gluteal tuberosity and the greater trochanter of the femur. The ultrasonography data was compared against that of a control group $(n=13,7$ men and 6 women) of the same age, in whom X-ray identified no hip pathology. Microsoft Excel 2000 and AtteStat were used for statistical processing. The quantitative characteristics of sample aggregates are presented in the respective tables in the form of a median with a level of $25-75 \%$ of the percentages and the number of observations (n) equal to the number of joints surveyed. The readings were processed by variation statistics methods applicable to small samples; the significance threshold was $\mathrm{p} \leq 0.05$. The Wilcoxon test was used for significance testing. Coxarthrosis stages were verified by X-ray.

The study protocol followed guidelines for experimental investigation with human subjects in accordance with the Declaration of Helsinki and was approved by the ethics committee. Written informed consent was obtained from each patient (or an official representative) before the study.

RESULTS. Pronounced degenerative and dystrophic changes of the hip in Stage III IC patients, as well as the pain syndrome, do alter the muscular functions related to locomotion and posture, which changes the biomechanical and EMG patterns of gait and standing upright [8]. It is the reduced ability to keep balance while walking and the reduced compensatory capabilities that define the locomotion stereotype of foot ground reaction force (GRF) in IC patients. In all patients, the affected limb was subject to lesser load, resulting in moderate (up to 25\%) asymmetry of foot loads while idling or walking; the walking pace was greatly reduced, as podograms showed 1.5 to 
2.0 times longer-than-norm step cycles symmetrically on both sides, while the double-support stage of the step cycle was 2.0 to 3.0 times longer than the norm. Both limbs had reduced joint movement amplitude and limited GRF, whereby the balancing and shock-absorption functions of the lower limb were affected. A lower load on one of the limbs with a more pronounced pain syndrome induced readable asymmetry of the temporal and force parameters of the step cycle; the muscles involved in locomotion were functionally impaired, and the patients performed compensatory body movements while walking, see Figure 1.

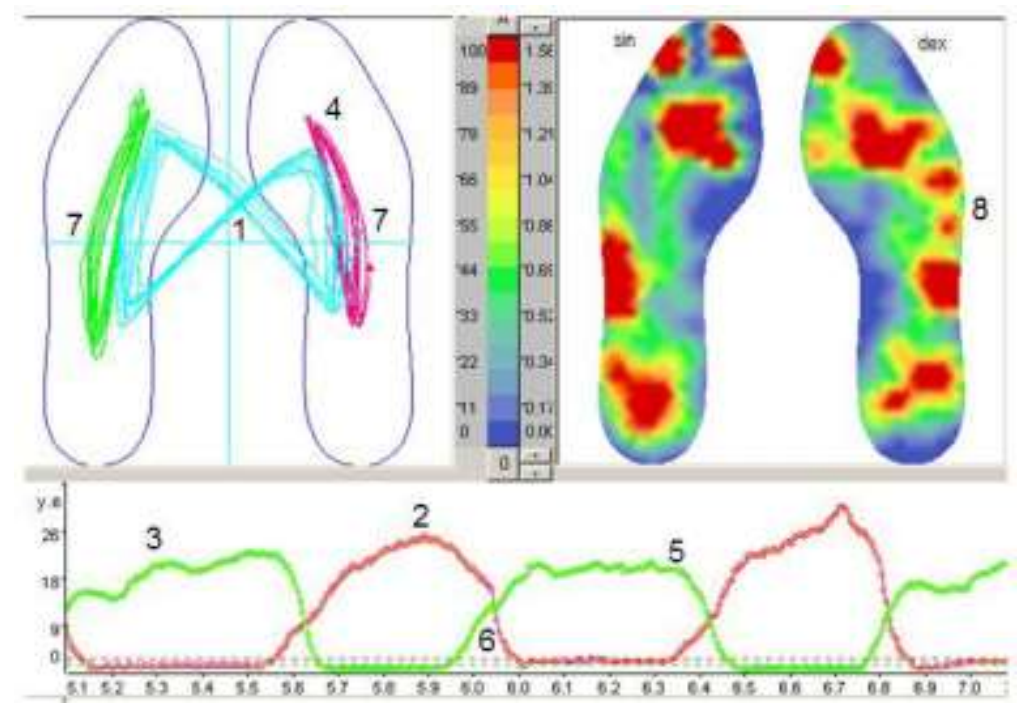

Figure 1. Podogram of Patient L., 65. Diagnosis: Stage III idiopathic coxarthrosis (before dextral hip replacement). Walking without additional support. Foot loading asymmetry: $32 \%$ when standing, 24\% when walking, $S>D$.

(Sin for the left limb, Dex for the right limb)

Asymmetric walking (1) with a right-side emphasis. Asymmetric temporal step parameters, Sin>Dex. The trough was smoothed (2) bilaterally; the ground reaction force was limited by the reduced flexion of proximal joints; the lower limb had a reduced shock-absorption function. Compensatory reduction in sinistral push-off (5), reduced maximum knee and hip flexion (nonpermanent). Asymmetric foot-ground interfacing (4), the asymmetric trajectory of the general center of pressure when walking (7) (Sin>Dex). A longer double-support period (6) and reduced ability to keep balance while walking. The trough distorted, see the additional wave of the impulse curve (3), meaning the patient performed compensatory movements while walking. Nonuniform right-side plantar surface pressure distribution (8), a sign of foot joint arthrosis.

The podogram shows the adaptive stereotypes of the feet stance responses. Either a bilateral increase in step variability or a greater increase in variability where the pain syndrome was more pronounced, a sign of (partial) loss of compensatory capabilities in walking [9]. Table 1 shows the calculated podography readings of State III coxarthrosis patients.

Sonic and geometric measurements showed that $\mathrm{m}$. rectus and $\mathrm{m}$. intermedius did not differ significantly in thickness in the affected limb vs the contralateral limb. M. rectus was $25 \%$ thinner 
in the affected limb, $22 \%$ in the contralateral limb in the treated patients compared to the controls; for $\mathrm{m}$. intermedius, the thinning was $36.9 \%$ and $41.4 \%$, respectively.

Table 1

Estimated podography values in Stage III idiopathic coxarthrosis patients

(Me $25-75 \%, \mathrm{n}$ is the number of observations)

\begin{tabular}{|c|c|c|c|}
\hline \multirow{2}{*}{ Indicator } & \multicolumn{3}{|c|}{ Limb } \\
\hline & $\begin{array}{c}\text { Affected } \\
(\mathrm{n}=25)\end{array}$ & $\begin{array}{l}\text { Conditionally intact } \\
(\mathrm{n}=25)\end{array}$ & Asymmetric \\
\hline Cycle time, seconds & $\begin{array}{c}1.02 \\
(0.81 \div 1.18)\end{array}$ & $\begin{array}{c}0.98 \\
(0.86 \div 1.01)\end{array}$ & $\begin{array}{c}0.89 \\
(0.83 \div 0.95)\end{array}$ \\
\hline Stance time, \% & $\begin{array}{c}47.0 \\
(29.0 \div 61.0)\end{array}$ & $\begin{array}{c}38.5 \\
(14.0 \div 65.0)\end{array}$ & $\begin{array}{c}0.78 \\
(0.52 \div 0.93)\end{array}$ \\
\hline $\begin{array}{l}2^{\text {nd }} \text { peak Ground reaction vertical forces } \\
\text { GRF (cond. units) }\end{array}$ & $\begin{array}{c}41.8 \\
(26.8 \div 54.6) \\
\end{array}$ & $\begin{array}{c}57.5 \\
(41.4 \div 74.2) \\
\end{array}$ & $\begin{array}{c}0.72 \\
(0.63 \div 0.76)\end{array}$ \\
\hline Area GRF, cond. units & $\begin{array}{c}4,069 \\
(3,693 \div 5,252 \\
)\end{array}$ & $\begin{array}{c}3,777 \\
(3,602 \div 7,317 \\
)\end{array}$ & $\begin{array}{c}0.89 \\
(0.75 \div 0.95)\end{array}$ \\
\hline $\begin{array}{l}1^{\text {st }} \text { peak as a proportion of the area } \\
\text { GRF, } \%\end{array}$ & $\begin{array}{c}24.4 \\
(19.7 \div 26.2)\end{array}$ & $\begin{array}{c}21.0 \\
(20.0 \div 23.3)\end{array}$ & $\begin{array}{c}0.82 \\
(0.75 \div 0.85)\end{array}$ \\
\hline $\begin{array}{l}2^{\text {nd }} \text { peak as a proportion of the area GRF, } \\
\%\end{array}$ & $\begin{array}{c}59.4 \\
(58.2 \div 61.5)\end{array}$ & $\begin{array}{c}57.1 \\
(56.8 \div 60.1)\end{array}$ & $\begin{array}{c}0.95 \\
(0.94 \div 0.96)\end{array}$ \\
\hline Step inertia ratio & $\begin{array}{c}0.90 \\
(0.58 \div 0.96)\end{array}$ & $\begin{array}{c}0.73 \\
(0.70 \div 0.79)\end{array}$ & $\begin{array}{c}0.82 \\
(0.62 \div 0.86)\end{array}$ \\
\hline \multicolumn{2}{|l|}{ Static foot loading asymmetry, $\%$} & \multicolumn{2}{|c|}{$0.78(0.68 \div 0.89)$} \\
\hline \multicolumn{2}{|l|}{ Dynamic foot loading asymmetry, $\%$} & \multicolumn{2}{|c|}{$0.75(0.64 \div 0.89)$} \\
\hline
\end{tabular}

The boundaries between $\mathrm{m}$. rectus and $\mathrm{m}$. intermedius were clearly visible, the muscles had preserved their striation. Note that in both limbs, fascicles were short (up to $1 \mathrm{~mm}$ ), and their inclination angle was almost as low as half of that in the controls. Compared to the controls, the affected-limb m. rectus had a $14 \%$ greater acoustic density due to the fibrous process.

M. iliopsoas is responsible for hip flexion, outward hip rotation, as well as forward torso flexion when the hip stands still. Ultrasound visualized somewhat blurred m. iliopsoas contours; isolated fascicles were linearly oriented, and the muscle was $25 \%$ thinner in the affected limb, $22 \%$ in the contralateral limb compared to the controls. Such emphasis on m. gluteus medius was necessary, as this muscle is involved in abducting the hip at the hip joint, prevents the pelvis from tilting towards the swung limb during single-support part of the gait cycle, rotates the hip internally, and facilitates foot takeoff. 
Idiopathic coxarthrosis patients had visible structural damage to m. gluteus medius: fascicles could not be differentiated, the muscular contour was blurred, the muscles were $70 \%$ thinner in the affected limb, $60 \%$ in the contralateral limb as compared to the controls.

M. adductor longus is involved in hip adduction and flexion. As a rule, Stage III idiopathic coxarthrosis patients have reduced hip adduction and abduction force. M. adductor longus dysfunction was associated with sonographic signs of its atrophy: the muscle became as thin as 3$5 \mathrm{~mm}$, while its acoustic density rose by $10 \pm 2 \%$ compared to the controls, see Figure $2 \mathrm{a}$.

M. gluteus maximus is a coarse-fibered and strong muscle that may reach 2 to $3 \mathrm{~cm}$ in thickness; it is designed to erect the forward-flexed torso, to extend the hip, to simultaneously pronate it, and to stretch the broad fascia of the thigh, see Figure $2 b$.

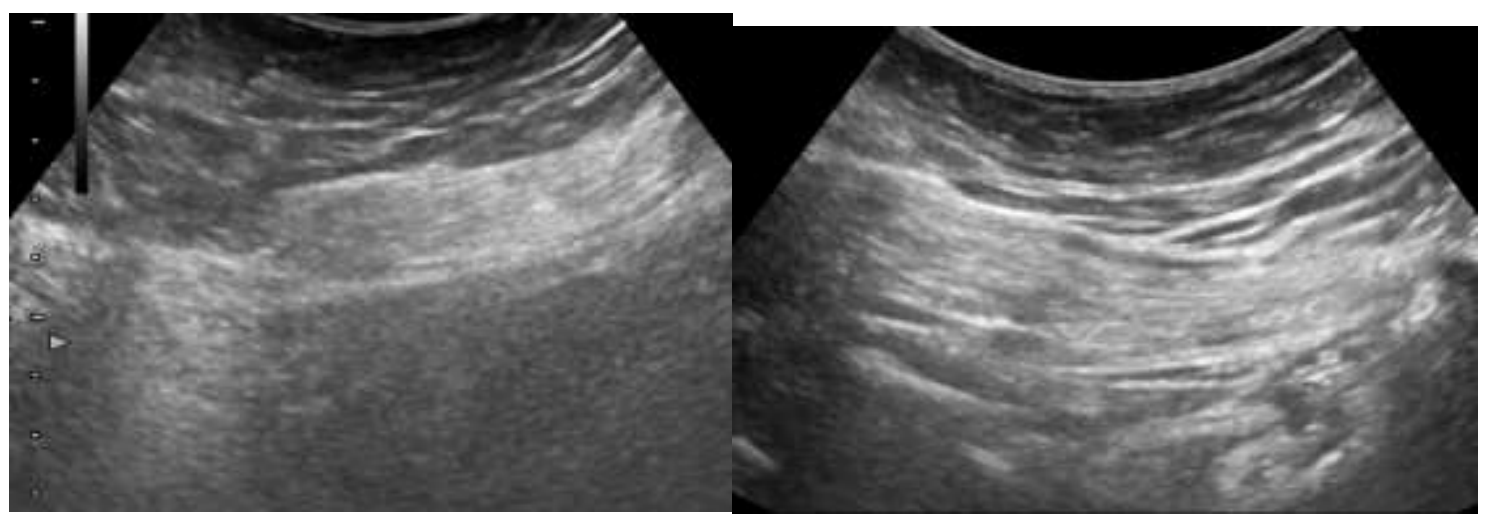

(a)

(b)

Figure 2. Sonogram of m. adductor (a) and m. gluteus maximus (b) of Patient $S, 71$.

Diagnosis: Stage III coxarthrosis

M. adductor had an acoustic density of $163 \mathrm{cu}$, m. gluteus maximus had $161 \mathrm{cu}$. In idiopathic coxarthrosis, the dynamometric readings of all tested muscles engaged in knee and hip movements were reduced significantly in both limbs to $20 \%$ to $70 \%$ of the average norm [7]. This reduction was symmetric except hip extensor strength. Testing the hip extensors by stretching (at maximum hip adduction) revealed a significant reduction in the muscular strength gain in idiopathic coxarthrosis patients (to 5\%). The length-strength function of active muscles depends on the contractive and elastic component ratio [9]. Conditional muscle stretch did not affect its functional readings in operation, a sign of morphological damage to the muscular structure, see Table 2.

Table 2

Dynamometric readings of hip muscles in Stage III

idiopathic coxarthrosis patients

\begin{tabular}{|c|c|c|c|}
\hline \multirow{2}{*}{ Muscle groups } & \multicolumn{3}{|c|}{ Limb } \\
\cline { 2 - 4 } & Affected & Conditionally intact & Asymmetric \\
\hline \multirow{2}{*}{ Tibial flexors } & 14.9 & 21.6 & 0.81 \\
& $(8.0 \div 20.6)$ & $(17.2 \div 26.7)$ & $(0.64 \div 0.98)$ \\
\hline \multirow{2}{*}{ Tibial extensors } & 15.0 & 24.0 & 0.67 \\
& $(6.3 \div 16.7)$ & $(14.5 \div 24.8)$ & $(0.53 \div 0.70)$ \\
\hline
\end{tabular}




\begin{tabular}{|c|c|c|c|}
\hline Hip flexors & $\begin{array}{c}73.6 \\
(64.3 \div 85.0)\end{array}$ & $\begin{array}{c}109.9 \\
(91.5 \div 115.7) \\
P^{*}=0.0306\end{array}$ & $\begin{array}{c}0.62 \\
(0.57 \div 0.88)\end{array}$ \\
\hline Hip extensors & $\begin{array}{c}90.6 \\
(57.5 \div 102.9) \\
\end{array}$ & $\begin{array}{c}106.4 \\
(100.5 \div 129.4)\end{array}$ & $\begin{array}{c}0.74 \\
(0.57 \div 0.78)\end{array}$ \\
\hline Hip adductors & $\begin{array}{c}87.4 \\
(70.0 \div 108.0)\end{array}$ & $\begin{array}{c}103.5 \\
(95.5 \div 118.3)\end{array}$ & $\begin{array}{c}0.85 \\
(0.73 \div 0.98)\end{array}$ \\
\hline Hip abductors & $\begin{array}{c}87.3 \\
(70.0 \div 108.0)\end{array}$ & $\begin{array}{c}103.5 \\
(95.5 \div 118.3)\end{array}$ & $\begin{array}{c}0.85 \\
(0.73 \div 0.98)\end{array}$ \\
\hline $\begin{array}{c}\text { Abduction at } \\
\text { max. adduction }\end{array}$ & $\begin{array}{c}97.5 \\
(77.5 \div 123.5) \\
\end{array}$ & $\begin{array}{c}120.5 \\
(104.9 \div 158.1) \\
\end{array}$ & $\begin{array}{c}0.62 \\
(0.49 \div 0.68) \\
\end{array}$ \\
\hline $\begin{array}{c}\% \text { gain at } \\
\text { max. adduction }\end{array}$ & $\begin{array}{c}5.35 \\
(0 \div 14.3)\end{array}$ & $\begin{array}{c}20.9 \\
(11.6 \div 50.2)\end{array}$ & $\begin{array}{c}0.14 \\
(0 \div 0.92)\end{array}$ \\
\hline
\end{tabular}

CONCLUSIONS. Stage III idiopathic coxarthrosis patients had more pronounced sonic signs of atrophy in the affected segment (reduced thickness, greater acoustic density, blurred contours) in $\mathrm{m}$. gluteus maximus and $\mathrm{m}$. adductor longus as compared to the contralateral segment. Frontal thigh muscles had moderate structural changes, where the affected segment and its contralateral counterpart had well-differentiable intermuscular septa, and the fascicles had the typical orientation, although their inclination angle was reduced by $18 \%$ to $25 \%$ compared to the controls. These signs indicate the frontal thigh muscles could provide some reserves for rehabilitation.

Structural functional parallels were co-oriented as shown by ultrasound scans and dynamometry. Locomotion stereotypes were dominated by the reduced functional activity of all the muscles involved in locomotion; compensatory body movements were registered when walking.

\section{FINANCIAL SUPPORT AND SPONSORSHIP}

Nil.

\section{CONFLICTS OF INTEREST}

The authors declare no conflict of interest

\section{SUPPLEMENTARY DATA (DOI)}

\section{REFERENCES}

1. Chegurov O.K., Kolesnikov S.V., Kolesnikova E.S. et al. Assessment of functional status in patients with different etiopathogenetic variants of stage III coxarthrosis [Otsenka funktsional'nogo statusa u bol'nykh s razlichnymi etiopatogeneticheskimi variantami koksartroza III stadia]. Genij Ortopedii - Genii Ortopedii, 2013, no 4, pp. 44-47.

2. Yefimov A.P. Clinically significant parameters of gait [Klinicheski znachimye parametry pokhodki] // Traumatology and Orthopedics of Russia - Travmatologia i ortopedia Rossii, 2012, no 1, pp.6065, doi https://doi.org/10.21823/2311-2905-2012-0-1-65-75 
3. Kolesnikov S.V., Kolchanov K.V., Kolesnikova E.S. et al. Conservative treatment evaluation in patients with II-III Stage coxarthrosis using different scales and tests [Otsenka konservativnogo lecheniia bol'nykh koksarzom II-III stadii po razlichnym shkalam i testam]. Genij Ortopedii - Genii Ortopedii, 2013, no 3, pp. 33-36.

4. Shaikhutdinov I.I., Eremeev A.M., Shul'man A.A. et al. Motornye otvety myshts bedra i goleni u bol'nykh artrozami krupnykh sustavov do i posle endoprotezirovaniia [Motornye otvety myshts bedra i goleni u bol'nykh artrozami krupnykh sustavov do i posle endoprotezirovaniia]. Practical Medicine - Prakticheskaia meditsina, 2016, vol. 96, no 4-1, pp.178-181.

5. Fedorov V.G. The term of structural unit «synovial joint». the main principles of the treatment of osteoarthritis and other degenerative diseases of synovial joints [Strukturnaia edinitsa «sinovial'nyi sustav» i osnovnye printsipy lecheniia osteoartroza i drugikh degenerativnykh zabolevanii sinovial'nogo sustava]. Advances in current natural sciences - Uspekhi sovremennogo estestvoznaniia, 2015, vol. 1, no. 4, pp. 594-600.

6. Smirnova L.M. Software and hardware complex for evaluation of anatom- functional disorders and efficiency of orthosis in foot pathology [Programmno-apparatnyi kompleks dlia otsenki anatomofunktsional'nykh narushenii i effektivnosti ortezirovaniia pri patologii stopy]. Medical equipment Meditsinskaia tekhnika, 2009, no 6, pp. 22-26.

7. Shchurov V.A., Dolganova T.I., Dolganov D.V. A Femoral Muscle Dynamometer [Ustanovka dlia izmereniia sily myshts bedra] Medical equipment - Meditsinskaia tekhnika, 2014, no 1, pp. 27-30.

8. Ephimov A.P. Informativity of biomechanical parameters of gait for the estimation of the lower extremities pathology [Informativnost' biomekhanicheskikh parametrov pokhodki dlia otsenki patologii nizhnikh konechnostei] Russian Journal of Biomechanics - Rossiiskii zhurnal biomekhaniki, 2012, no. 1, pp.80-88.

9. Samsonova A.V. Human skeletal muscle hypertrophy: tutorial [Gipertrofiia skeletnykh myshts cheloveka: uchebnoe posobie]. 3-rd edition, St. Petersburg, Politekhnika, 2015, 159 p. 